\title{
Leptadenia hastata: A Review of its Traditional uses and its Pharmacological Activity
}

\section{Steven D. Thomas*}

The Graduate School, Michigan State University, East Lansing, MI 48824, USA

\begin{abstract}
Leptadenia hastata (Pers.) Decne is often used traditionally for hypertension, catarrh, skin diseases, woundhealing, prostate complaints and as an aphrodisiac. In traditional systems of medicine, different parts are used including the leaves, latex, roots and even whole plant. Leptadenia hastata is reported to contain alkaloids, saponins, phenolic glycosides, tannins, flavonoids, proanthocyanidins and triterpenes. This review describes the medicinal properties, chemical constituents, and other important aspects of Leptadenia hastata.
\end{abstract}

Keywords: Leptadenia hastata; Antimicrobial; Anti-inflammatory; Wild food; Diabetes; Traditional medicine; Wound-healing

\section{Introduction}

Leptadenia hastata is edible non-domesticated vegetable and it is collected in wild throughout Africa. L. hastata is a voluble herb with creeping latex stems, glabescent leaves, glomerulus and racemus flowers as well as follicle fruits. It is typically grown in tropical dry lands in sandy soil. Wild foods like L. hastata provide food security during seasonal changes and are used medicinally in many areas. Vernacular names for L. hastata include: hagalhadjar (Arabic) in Chad, yadiya (Hausa) in Nigeria and Niger, hayla (Kusume) Ethiopia, ekamongo (Turkana) in Kenya, lolongo (Moore) in Burkina Faso, tarhat or darhat (Wolof), busumba amata (Jola) in Senegal, and nzongnè (Bambara) in Mali.

\section{Traditional Uses}

Decoction of the leaves of L. hastata with the bark of Erythrina senegalensis is either taken orally or used as a medicinal bath to treat onchocercosis in Mali [1]. In Chad, the roots are used to treat scabies [2]. This plant is commonly used in Hausa-speaking communities in Nigeria as a spice and used in sauces [3]. Also in Nigeria, local healers use the plant for hypertension, catarrh and skin diseases [4]. In Burkina Faso, locally it is used for sexual potency (chewing leaves), trypanosomosis (decoction of leaves), skin diseases and wound-healing (application of latex) [5]. In Senegal, the leaves have been reportedly used for lactation and as a purgative by Kerharo and Adam and Arbonnier [6,7]. Senegalese healers also use the L. hastata for prostate and rheumatism complaints [8].

\section{Phytochemical Analysis and Nutritional Value}

A phytochemical screening conducted by Bello et al. on L. hastata leaves indicate the presence of phenolic glycosides, tannins, flavonoids, proanthocyanidins, alkaloids and saponins [9]. The total phenolic, total flavonoid and proanthocyanidin contents were in the ranges of 17-38, $10-16$ and $4-10 \mathrm{mg} / \mathrm{g}$ respectively depending on the extraction solvent.

In their study, they report that the acetone extract had highest content of total phenol $(35.77 \mathrm{mg} / \mathrm{g})$ than the methanol extract and aqueous extract. The flavonoids content of methanol fraction (15.85 $\mathrm{mg} / \mathrm{g}$ ) is higher than that of acetone and water extracts. The methanol extract $(9.69 \mathrm{mg} / \mathrm{g})$ had highest content of proanthocyanidins compared to water and acetone.

Aquino et al. have revealed that the chloroform extract of L. hastata bark contains mixtures of polyoxypregnane ester derivatives, including six novel esters, as well as the known esters 12-O-acetylsarcostin (penupogenin), gagaminin, kidjolanin, metaplexigenin and cynanforidin [10]. Gagaminin derivatives have been reported to have antibacterial activity [11].

Work done by Nikiéma et al. found that L. hastata contains triterpenes like lupeol, lupeol acetate and lupeol palmitate [12]. In studies by Sena et al. and Freiberger et al. reveals fatty acids $(23.2 \mathrm{mg} / \mathrm{g}$ dry weight) with large amounts of $\alpha$-linolenic acid, lutein $(53.8 \mu \mathrm{g} / \mathrm{g}$ dry weight), $\beta$-carotene $(50.8 \mu \mathrm{g} / \mathrm{g}$ dry weight), protein, and eight essential amino acids $[13,14]$. L. hastata is also found to be a rich source of copper, calcium, and phosphorus [14].

\section{Pharmacological Activity}

\section{Antimicrobial activity}

Aliero and Wara investigated the effect of $L$. hastata leaf extracts on Bacillus metagarium, Staphylococcus aureus, Escherichia coli, Salmonella paratyphi and Pseudomonas aeruginosa [15]. Aqueous extract markedly inhibited the growth of S. paratyphi and E. coli at 30 $\mathrm{mg} / \mathrm{ml}$ and $P$. aeruginosa at $60 \mathrm{mg} / \mathrm{ml}$. The activity exhibited by the methanol extract was generally low and acetone extract did not show any activity against the tested organisms.

Aliero and Wara [15] also examined in the same study the antifungal activity of L. hastata extracts with Aspergillus niger and Fusarium oxysporum. The result of their assays showed that methanol extract suppressed the growth of F. oxysporum and A. niger at $80 \mathrm{mg} / \mathrm{ml}$ with inhibition percentages ranging from 58.89 to $73.30 \%$. The activity of acetone extract was lower with 40 and $50 \%$ inhibition respectively on the growth of $A$. niger and F. oxysporum.

\section{Anti-androgenic activity}

Bayala et al. demonstrated a competitive effect of the aqueous extracts of $L$. hastata leaf steams and the testosterone propionate (TP) on castrated immature Wistar rats [16]. They found that the anti-

*Corresponding author: Steven D. Thomas, The Graduate School, Michigan State University, East Lansing, MI 48824, USA, Tel: 517-353-3262; Fax: 517-353-3355; E-mail: sdthomas25@gmail.com

Received December 03, 2012; Accepted December 18, 2012; Published December 20, 2012

Citation: Thomas SD (2012) Leptadenia hastata: A Review of its Traditional uses and its Pharmacological Activity. Med chem 2:148-150. doi:10.4172/21610444.1000132

Copyright: (c) 2012 Thomas SD. This is an open-access article distributed under the terms of the Creative Commons Attribution License, which permits unrestricted use, distribution, and reproduction in any medium, provided the original author and source are credited. 
androgenic effect of the extract of $L$. hastata is expressed when the TP amounts are weak. Concentrations of TP ranged from $0.04-1,000 \mu \mathrm{g} /$ $\mathrm{kg}$ of TP. At low doses of TP, L. hastata (at $200 \mathrm{mg} / \mathrm{kg}$ ) inhibited TP effects, whereas at high doses of TP, L. hastata extracts potentiated TP effects. To further evaluate the competition between TP and L. hastata extracts, Bayala et al. conducted a follow-up study [16]. In this 2012 experiment, $L$. hastata aqueous extracts reduced significantly the weight of androgen-dependent sex glands, the level of phosphatase acid prostatic (PAP) and fructose in seminal vesicles and prostate, and the serum testosterone level [17]. L. hastata extract concentrations ranged from $100-400 \mathrm{mg} / \mathrm{kg}$. This study showed that the low doses of L. hastata increased TP activity and the high doses inhibited its action. These results confirmed the anti-androgenic effects of L. hastata extracts and have implications on prostate cancer treatment and reproductive health [18-20].

\section{Anti-inflammatory activity}

Nikiéma et al. examined triterpenes isolated from L. hastata latex for their anti-inflammatory activity. Lupeol, lupeol acetate and lupeol palmitate were found to be the main anti-inflammatory constituents in the croton oil-induced ear oedema test [21].

All the triterpenes tested at a dose of $0.42 \mu \mathrm{mol} / \mathrm{ear}$ induced a significant reduction of oedema. Lupeol exhibited $80 \%$ inhibition of oedema and was found to be more active than indomethacin (73\%). Nikiéma also found that lupeol hemisuccinate, a synthetic derivative of lupeol exhibited a higher activity than lupeol, in the oedema test.

Wound-healing: The results from the Nikiéma et al. [21] study verify the topical use of $L$. hastata latex in wound-healing. Their experiments examined an in vitro model of human skin keratinocytes (epidermal explants) cultured at an air-liquid interface on a deepidermized human dermis (DED) to investigate the effects of lupeol esters on skin repair.

Compared with the control, lupeol acetate and lupeol palmitate improved keratinocyte proliferation at a concentration of $5 \mu \mathrm{M}$ in the culture medium. However, lupeol hemisuccinate induced a sufficient differentiation of keratinocytes with a well-formed stratum corneum without parakeratosis.

\section{Anti-diabetic activity}

The results of another Bello et al. study also demonstrated the potential of $L$. hastata extracts in diabetes mellitus management [22]. Their study, they evaluated the hypoglycaemic and hypolipidaemic effects of water and methanol extracts of the fresh leaves L. hastata in normal and alloxan-induced diabetic rat model. Rats were given $300 \mathrm{mg} / \mathrm{kg}$ body weight of plant extract per day in the morning hours for seven days. Oral administration of methanol and water extracts showed a significant decrease the blood glucose, while increasing liver and muscle glycogen levels. L. hastata extracts also reduced of serum triglyceride, VLDL (very low density lipoprotein) cholesterol levels and increased HDL (high density lipoprotein) cholesterol levels. Another indication of $L$. hastata, therapeutic effects was its a-glucosidase inhibitory properties [9]. Bello's results show that both the methanol and water extracts of $L$. hastata leaf significantly inhibited the activity of a-glucosidase.

\section{Cytotoxicity}

Aquino et al. [10] tested isolated compounds from the bark chloroform-methanol fractions for their cytotoxic activity on Raji cells (a human lymphoblastoid cell line from Burkitt's lymphoma).
However, their results shown no activity at concentrations evaluated $(0.5$ and $1.0 \mu \mathrm{g} / \mathrm{ml})$ after six hours of incubation [10].

\section{Toxicity and safety}

Tamboura et al. [5] conducted their experiments by the means of male albino mice using concentrations $1000-2000 \mathrm{mg} / \mathrm{kg}$ body weight of $L$. hastata aqueous extract (leaves and stems). The mice were injected with the extract intraperitoneally and were observed during 48 to 72 hours. According to Tamboura et al., L. hastata is considered safe to use due to its high LD quotient value of 0.78 [5].

\section{Conclusion}

The review is an attempt to provide the ecological, phytochemical, ethnopharmacological, and pharmacological information on L. hastata, a wild vegetable used traditionally for culinary and medicinal purposes. The literature survey publicizes that L. hastata contains alkaloids, saponins phenolic glycosides, tannins, flavonoids, proanthocyanidins and triterpenes.

This vegetable shows antibacterial, antifungal, anti-inflammatory, anti-androgenic, anti-diabetic activities. There are many other traditional uses of L. hastata throughout Africa which serves as the basis for further studies. In addition to filling the gaps of food security, wild functional foods like L. hastata, deserve additional study and conservation efforts because of their role in local economies and health care treatments.

\section{References}

1. Togola A, Austarheim I, Theïs A, Diallo D, Paulsen BS (2008) Ethnopharmacological uses of Erythrina senegalensis: a comparison of three areas in Mali, and a link between traditional knowledge and modern biological science. J Ethnobiol Ethnomed 4: 6.

2. Betti JL, Yemefa'a SRM, Nchembi Tarla F (2011) Contribution to the knowledge of non wood forest products of the far north region of Cameroon: Medicinal plants sold in the Kousséri market. J Ecol Nat Environ 3: 241-254.

3. Ibrahim HA, Ali GY, Halliru SN, Usaini S, Abdullahi II (2012) Ethnobotanical Survey of the Wild Edible Food Plants Consumption among Local Communities in Kano State, North-Western, Nigeria. International Journal of Science and Technology 2: 713-717.

4. Dambatta SH, Aliyu BS (2011) A survey of major ethnomedicinal plants of Kano North Nigeria, their knowledge and uses by traditional healers. Bayero Journa of Pure and Applied Sciences 4: 28-34.

5. Tamboura HH, Bayala B, Lompo M, Guissou IP, Sawadogo L (2005) Ecologica distribution, morphological characteristics and acute toxicity of aqueous extracts of Holarrhena floribunda (G. Don) Durand \& Schinz, Leptadenia hastata (Pers.) Decne and Cassia sieberiana (dc) used by veterinary healers in Burkina Faso. Afr J Trad CAM 2: 13-24.

6. Kerarho J, Adam JG (1974) The traditional Senegalese pharmacopoeia: Medicinal and poisonous plants. Vigot brother's edition, Paris.

7. Arbonnier M (2000) Trees, shrubs and vines dry areas of West Africa

8. Mathieu G, Meissa D (2007) Traditional leafy vegetables in Senegal: diversity and medicinal uses. Afr J Tradit Complement Altern Med 10: 469-475.

9. Bello A, Aliero AA, Saidu Y, Muhammad S (2011) Phytochemical Screening Polyphenolic Content and Alpha-Glucosidase Inhibitory Potential of Leptadenia hastata (Pers.) Decne. Nigerian Journal of Basic and Applied Science 19: 181 186.

10. Aquino R, Peluso G, De Tommasi N, De Simone F, Pizza C (1996) New polyoxypregnane ester derivatives from Leptadenia hastata. J Nat Prod 29 : 555-564.

11. Hwang BY, Kim SE, Kim YH, Kim HS, Hong YS, et al. (1999) Pregnane glycoside multidrug-resistance modulators from Cynanchum wilfordii. J Nat Prod 62: 640-643.

12. Nikiéma JB, Vanhaelen-Fastré R, Vanhaelen M (1997) Triterpenoids from Leptadenia hastata latex. Planta Med 63: 486 
Citation: Thomas SD (2012) Leptadenia hastata: A Review of its Traditional uses and its Pharmacological Activity. Med chem 2:148-150. doi:10.4172/2161-0444.1000132

13. Sena LP, Vanderjagt DJ, Rivera C, Tsin AT, Muhamadu I, et al. (1998) Analysis of nutritional components of eight famine foods of the Republic of Niger. Plant Foods Hum Nutr 52: 17-30.

14. Freiberger CE, Vanderjagt DJ, Pastuszyn A, Glew RS, Mounkaila G, et al. (1998) Nutrient content of the edible leaves of seven wild plants from Niger. Plant Foods Hum Nutr 53: 57-69.

15. Aliero AA, Wara SH (2009) Validating the medicinal potential of Leptadenia hastata. Afr J Pharm Pharmacol 3: 335-338.

16. Bayala B, Rubio-Pellicer MT, Zongo M, Malpaux B, Sawadogo L (2011) Antiandrogenic activity of Leptadenia hastata (Pers.) Decne: competitive effect of the aqueous extracts of the plant and the testosterone propionate on castrated immature rats. Biotechnol Agron Soc Environ 15: 223-229.

17. Bayala B, Téléfo PB, Savadogo A, Sawadogo L, Malpaux B (2012) Combined effects of testosterone propionate and Leptadenia hastata Pers. (Decne) aqueous extracts on immature castrated male rats. J Med Plants Res 6: 29252931.
18. Bayala B, Telefo PB, Bassole IHN, Tamboura HH, Belemtougri RG, et al (2011) Anti-spermatogenic activity of Leptadenia hastata (Pers.) Decne leaf stems aqueous extracts in male Wistar rats. J Pharmacol Toxicol 6: 1-9.

19. Bayala B, Pellicer-Rubio MT, Bassole IHN, Belemtougri R, Tamboura HH, et al. (2011) Effects of aqueous extracts of Leptadenia hastate (pers.) decne. (asclepediaceae) on male reproductive functions using castrated immature rats. Res J Med Plant 5: 180-188.

20. Ogbuewu IP, Unamba-Oparah IC, Odoemenam VU, Etuk IF, Okoli IC (2011) The potentiality of medicinal plants as the source of new contraceptive principles in males. N Am J Med Sci 3: 255-263.

21. Nikiéma JB, Vanhaelen-Fastré R, Vanhaelen M, Fontaine J, De Graef C, et al (2001) Effects of antiinflammatory triterpenes isolated from Leptadenia hastata latex on keratinocyte proliferation. Phytother Res 15: 131-134.

22. Bello A, Aliero AA, Saidu Y, Muhammad S (2011) Hypoglycaemic and Hypolipidaemic Effects of Leptadenia hastata (Pers.) Decne in Alloxan Induced Diabetic Rats. Nigerian Journal of Basic and Applied Science 19: 187-192. 